\title{
The Role of Management Practice and Business Environment in Promoting Firm Innovativeness
}

\author{
Article history: \\ Received: 25 February 2016 \\ Sent for revision: 20 March 2016 \\ Received in revised form: 28 October 2016 \\ Accepted: 4 November 2016 \\ Available online: 30 December 2016
}

\begin{abstract}
The aim of this research is to identify the relationships between management practices and firm innovativeness on the one hand and business environment and firm innovativeness on the other. The research subject is the new management practices explored through two sides of the coin of management, like innovative management functions and roles, factors of dynamic business environment and organization innovation rate. The methodology that was used includes the application of statistical methods such as Spearman's correlation and MANOVA. Relying on data from 50 large organizations in Serbia, this study shows that, as well as some managerial roles, innovation-oriented planning, staffing leading and controlling stand in positive correlation to higher firm innovativeness. Furthermore, it explains differences in the degree of firm innovativeness depending on the nature of planning, staffing and leading. Given that firms usually operate in a dynamic business environment, empirical results regard changes in customer preferences, competition and technology as important contingency factors of firm innovativeness. The obtained results are useful for encouraging innovative ways of doing business which can be the base for developing a practical framework of new management practices which enhance firm innovativeness. However, empirical studies investigating the relative importance of innovative management practices are scarce, and therefore our study will attempt to fill the gap and open the way for further research into this area.
\end{abstract}

\footnotetext{
${ }^{1}$ University of Novi Sad, The Faculty of Economics Subotica, m.strugar,jelaca@ef.uns.ac.rs
} 
Strugar Jelača M.: The Role of Management Practice and Business Environment in...

Keywords: management innovation, dynamic business environment, firm innovativeness, large organizational systems

\section{Uloga menadžerske prakse i poslovnog okruženja u podsticanju veće inovativnosti organizacije}

Apstrakt: Cilj istraživanja ogleda se u utvrđivanju veza između menadžerskih praksa $i$ inovativnosti organizacije sa jedne $i$ poslovnog okruženja $i$ inovativnosti organizacije sa druge strane. Predmet istraživanja je nova menadžerska praksa koja se posmatra kroz dve strane medalje upravljačkog procesa, kao što su inovativno orijentisane menadžerske funkcije $i$ uloge, elementi dinamičnog poslovnog okruženja i stepen inovativnosti organizacije. Metodologija koja je korišćena obuhvata primenu statističkih metoda kao što su Spirmanov koeficijent korelacije i MANOVA. Oslanjajući se na podatke iz 50 velikih organizacionih sistema u Srbiji, rezultati ukazuju, kao što pojedine upravljačke uloge, tako i inovativno orijentisano planiranje, kadrovanje, vođenje $i$ kontrola pozitivno koreliraju sa višim stepenom inovativnosti organizacije. Takođe, ističu se razlike u stepenu inovativnosti organizacije $u$ zavisnosti od prirode funkcije planiranja, kadrovanja i vođenja. S obzirom da oorganizacije najčešće posluju u dinamičnom poslovnom okruženju, empirijski rezultati ukazuju da promene potrošačkih preferencija, konkurencije $i$ tehnologije predstavljaju značajne kontigentne faktore inovativnosti organizacije. Dobijeni rezultati su korisni za podsticanje inovativnog načina poslovanja što može da bude osnova za razvijanje praktičnog okvira nove menadžerske prakse koja unapređuje inovativnost organizacije. Empirijska istraživanja usmerena na analizu značaja inovativno orijentisanih menadžerskih praksi su oskudna, stoga smo ovim radom pokušali da smanjimo gep i otvorimo put novim istraživanjima.

Ključne reči: inovacije u oblasti menadžmenta, dinamično poslovno okruženje, inovativnost organizacije, veliki organizacioni sistemi

\section{Introduction}

Contemporary firms face a challenge, not only in innovating their product portfolio and technological capabilities, but also in introducing innovation into non-technological areas such as management. If organizations are to survive in the dynamic business environment, they must use appropriate managerial concepts (Potocan, Nedelko, \& Mulej, 2012, p. 291; Mamula \& PopovićPantić, 2015, p. 51), which will strengthen firm innovativeness. In modern-day conditions, it is vital for managers to concentrate on management innovation by means of innovating management practices through daily enhancement of 
Strugar Jelača M.: The Role of Management Practice and Business Environment in...

their activities within processes and operations within activities (Kharović \& Krstić, 2015, p.68)

Surprisingly, six years ago, research into management innovation accounted for only about 3 percent of innovation research (Crossan \& Apaydin, 2010). Although management innovation is an insufficiently researched form of innovation, a large number of authors (Guillen, 1994; Kaplan, 1998; Mazza \& Alvarez, 2000; Mol \& Birkinshaw, 2009; Vaccaro, Jansen, Van den Bosch, \& Volberda, 2012; Volberda, Van Den Bosch, \& Heij, 2013) have recognized their significance in the context of the dynamic business environment inspiring changes in traditional management practices. Particularly in recent years, scholars have shown a renewed interest in management innovation, creating new organizational practices, processes, and techniques (Mol \& Birkinshaw, 2014). This situation brings to the forefront the open, yet fundamental, question of how firms can stimulate change in the way the management do their work (Oli, 2012).

The central research objective of the paper is to establish the role of new management practices as a type of management innovation and dynamic business environment in promoting higher firm innovativeness. New management practices were observed from the angle of innovative management functions and managerial roles in large organizational systems. The authors' intention was to provide an answer to the question: How and in what way do innovative management functions and managerial roles, together with the dynamic business environment, affect innovativeness in large organizational systems. To that end, the following objectives were set in the study:

- to identify innovative management functions in large organizations in Serbia, as well as their correlation to the degree of firm innovativeness;

- to display the use of Mintzberg managerial roles and their correlation to the degree of firm innovativeness and

- to determine the dynamics of the business environment and their correlation to the degree of firm innovativeness.

For the purpose of the above-mentioned research, respondents comprised the top-level managers of 50 large organizational systems in the Republic of Serbia, covering all business sectors and regions. In order to answer the research question, the data obtained was tested using correlation analysis and MANOVA through the SPSS 20.0 software package.

The significance of the paper is in bridging the gap between research and practice of management innovation by broadening the understanding of internal prerequisites such as new management practices and performance consequences for the implementation of innovation on the firm level. The novelty of the paper is in representing the first empirical analysis in the field of 
Strugar Jelača M.: The Role of Management Practice and Business Environment in...

management innovation on the territory of the Republic of Serbia, which will provide useful managerial implications by recommending which management functions should be innovated and which managerial roles should be used to improve firm innovativeness.

\section{Literature review}

Given that firms encounter escalating competition and an accelerating rate of technological change, the long-existing paradigm of industrial innovation relying on technological inventions appears nowadays to co-occur with other forms of innovation such as management innovation (Volberda et al., 2013, p. 2 ), which is harder to replicate. Hence, numerous authors summarized in their research their views on the significance of management innovation for successful contemporary business, in view of the fact that it "will be a critical success factor for 21st century companies" (Feigenbaum \& Feigenbaum, 2005 , p. 96), as it contributes to overall organizational performance (Birkinshaw \& Mol, 2006; Ichniowski, Shaw, \& Prennushi, 1997; Pil \& MacDuffie, 1996; Volberda et al., 2013).

Attention is devoted to the role of management innovation as the process of formulation and implementation of new management practices, processes, structures of techniques aimed at improving organizational goals (Birkinshaw, Hamel, \& Mol, 2008, p. 829, Hamel, 2006). Management innovation is the function of achieving long-lasting advantage if they meet one of three conditions: (1) that the innovation is based on a novel principle that challenges management orthodoxy; (2) that it is systemic, encompassing a range of processes and methods; that innovation is part of an ongoing program of invention, which will result in progress over time (Hamel, 2006, p. 74). From the viewpoint of the first condition, we analyzed the novelty of managerial activities in the firm in comparison with traditional management concepts, such as the generally accepted concept of management functions defined by H. Fayol (Fayol, 1949) on the one hand, and on the other, the concept of managerial roles defined by $\mathrm{H}$. Mintzberg (Mintzberg, 1973; Mintzberg, 1975). Defined traditional concepts should be subjected to continuous change in order to keep pace with novelty. From the viewpoint of the second condition, it is particularly thought-provoking to investigate the span of implemented management innovation. Organizations could be oriented to innovating discrete functional activity, for instance, the planning function or the human resource function (incremental management innovation), or influencing several functions within the organization and the connections between them as systemic management innovation (Mol \& Birkinshaw, 2014, p. 11). To meet the third condition, we analyzed whether the company innovated some of these functions and achieved positive results 
Strugar Jelača M.: The Role of Management Practice and Business Environment in...

such as higher firm innovativeness. In spite of the growing recognition of the significance of management innovation, the empirical basis for measuring management innovation is still insufficient, in view of the fact that this area of research is currently in its infancy, and it is vital to have a certain degree of diversity in definitions (Volberda et al., 2013, p. 10). As management innovation covers changes in the 'how and what' managers do in setting directions, making decisions, coordinating activities and motivating people (Hamel, 2006; Van den Bosch, 2012), the term of management innovation in the paper in the field of innovative management functions and managerial roles.

As regards the first management function, strategic planning was old innovation in the field of management, first implemented in Ford in 1946 (Mol \& Birkinshaw, 2014). Today, successful planning should focus on identifying policies, procedures, rules and business strategies that are innovatively oriented. Procedures and rules set in such a way may encourage management to implement the functions of research (Quiang, Maggitti, Smith, Tesluk, \& Katalia, 2013, p. 894), which are indispensable for innovation. Therefore, planning should focus on scenario planning (Drew, 2006), discovery-driven planning (McGrath, 2010), targeted planning (O'Sullivan \& Dooley, 2009), contingent and flexible planning. As far as organizational function is concerned, the multidivisional configuration of DuPont and General Motors was the exemplary type of management innovation (Chandler, 1962). Nowadays, firms should be focused on the implementation of innovative organizational mechanisms, such as project organization (BlindenbachDriessen \& Van Den Ende, 2010), a generator and incubator of ideas, the holistic sequential model (O'Connor \& DeMartino, 2006) and ambidextrous organization (Gupta, Smith, \& Shalley, 2006; Diaz Fernandez, Pasamar Reyes, \& Valle Cabrera, 2012). As a function of management, staffing should provide a workforce that can offer a varied resource of creativity and flexibility (Sawhney, 2013). As well as creative, educated workforce (Mol \& Birkinshaw, 2009), are vital for realizing management innovation. Mamula and Kužet (2015) point out that businesses increasingly depend on extensive knowledge of their staff and use their suggestions and proactive approach resulting in innovation (as cited in Mamula \& Popović-Pantić, 2015, p. 51). During innovative oriented staffing function, emphasis should be placed on a business approach that is based on knowledge, which requires education followed by dissemination of knowledge among the employees and teams (Stefanović, 2015, p. 49). The leadership function effectively stimulates innovative way of thinking (Vaccaro, 2010, p. 27). Innovation oriented leadership refers to the extent to "which leaders promote subordinates" innovation orientation" (Stock \& Zacharias, 2011, p. 874). The manager as a leader should be focused on encouraging innovative spirit through the application of transformative, charismatic and team-oriented leadership 
Strugar Jelača M.: The Role of Management Practice and Business Environment in...

(Hartog, Van Muijen, \& Koopman, 1997; Gumusluoglu \& Ilsev, 2009; Moriano, Molero, Topa, \& Lévy Mangin, 2014). It is also important to conform control as a function of management - to an organization's innovative activities; this depends on the size of an organization, its implemented organizational structure and its prevailing style of management (Chiesa, Frattini, Lambertiand, \& Noci, 2009, p. 422).

Bearing in mind the previously stated innovation in management functions as the type of management innovation, which is frequently an antecedent of technological innovation (Mol \& Birkinshaw, 2012), and can also convey a powerful advantage to the innovating firm (Hamel, 2006), we have set hypothesis $\mathrm{H} 1$. The aim of $\mathrm{H} 1$ is to establish a link between the innovative management functions and firm innovativeness.

Starting from the assumption that actions performed by individuals within the organization, resulting in creation of managerial innovations (Birkinshaw et al., 2008 , p. 826) and that management practices refer to what managers do as a segment of their job on a daily basis (Birkinshaw et al., 2008; Mol \& Birkinshaw, 2009), hypothesis $\mathrm{H} 2$ is aimed at finding the relation between implemented managerial roles and firm innovativeness. Being one of the managerial roles, a leader should perform the following roles within the framework of implementation of innovative activities: forming a team, defining the mission, goals and expectations, conducting team members' training, solving problems, managing limitations, and challenges, supporting selfmanagement among the team members etc. (Morgeson, DeRue, \& Karam, 2010, p. 9).

The crucial aim of the mentioned hypothesis is to define the innovative way of doing business, and if we want to do that, it is necessary to change the structure of the system and set up such a structure that will promote and facilitate the implementation of the desired business behaviour (Markides, 2013 , p. 316). The ultimate goal of implementing management innovation should be the establishment of a new business model, which indicates the content, structure, and governance of transactions designed to create value through using the possibilities (Amit \& Zott, 2001, p. 511). It relates to finding new business logic in an organization, as well as creating new values for stakeholders through income-generation and ultimately defining new propositions for consumers, suppliers and business partners (CasadesusMasanell \& Zhu, 2013, p. 464).

The influence of the external environment on innovativeness has been widely recognized (Zahra 1996, Zahra \& Bogner, 2000). It is particularly interesting to analyze the correlation between dynamic environment and firm innovativeness because emerging market situations have driven firms to be more innovative and apply the strategy of change with constant innovations (Mamula \& Popović-Pantić, 2015, p. 49). Given that the rate and continuity of 
Strugar Jelača M.: The Role of Management Practice and Business Environment in...

change within an industry are reflected by dynamism (Zahra \& Bogner, 2000, p. 136), dynamic environments may be characterized by modifications in technologies, variations in customer preferences, and fluctuations in product demand or supply of materials (Jansen, Van Den Bosch, \& Volberda, 2006, p. 1664 ) as well as the entry or exit of competitors (Boyd, Dess, \& Rasheed, 1993).

Based on the previous statements, hypothesis $\mathrm{H} 3$ was set, which takes into account the connection between the dynamic movements of the internal and external factors of the business environment and firm innovativeness.

\section{Research methodology}

\subsection{The sample}

Our survey covered the management of 50 large organizational systems across the territory of the Republic of Serbia and was conducted during 2012 and 2013. Following Birkinshaw et al. (2008), we propose that managers as internal change agents play a particularly relevant role as they are the individuals championing the introduction of management innovation in order to make organizations more effective. On the other hand, the focus was on large organizational systems because they are more resourceful than smaller ones, and their need to introduce new management innovations is also more manifest (Kimberly \& Evanisko, 1981; Mol \& Birkinshaw, 2009). As far as larger, more complex, organizations and innovation are concerned, previous studies have offered contradictory evidence (Vaccaro et al., 2012, p. 35). Despite emphasizing the importance of large organizations, it was believed earlier that they are unattractive due to the high levels of bureaucracy and the numerous business policies that limit the freedom that is essential for making the employees creative. However, large companies can take on greater risks when researching, and therefore their efforts may result in larger innovations, i.e. radical innovations (Symeonidis, 1996; Aranda, Rata, \& Duarte, 2001).

\subsection{The design of the survey, conceptual framework and hypotheses}

In existing research investigating the outcomes and antecedents of management innovations, a common agreement reiterates that it increases firm performance, but the influence how new management practice (innovative management functions and roles) affect firm innovativeness still remain unexplored. 
Strugar Jelača M.: The Role of Management Practice and Business Environment in...

During theoretical development of the survey variables we used the most frequently quoted papers:

- Given that a universal scale of management innovation is still unavailable (Vaccaro et al., 2012, p. 38), we had to develop a new measure for this concept in the present study. When setting the scale that describes the independent variable (new management practice) we used different, but complementary definitions of management innovation (Birkinshaw et al., 2008; Hamel, 2006; Kimberly \& Evanisko, 1981; Mol \& Birkinshaw, 2009) that have guided us while generating a pool of items. Also, we used some items from Vaccaro et al. (2012) scale for measuring management innovation.

- Describing the other independent variable, dynamic business environment, we used the classification of environmental factors given by Bourgeois and Eisenhardt (1988) and a modified scale of Jaworski and Kohli (1993), so that the original items were translated and adjusted for the purpose of this study.

- When measuring the dependent variable, firm innovativeness, we took into account the fact that there are various definitions and criteria of firm innovativeness (Green, Gavin, Aiman-Smith, 1995; Garcia \& Calantone, 2002). We used the definition that firm innovativeness is most frequently viewed through a number of innovations that the organization accepts and produces (Subramanian \& Nilakanta, 1996; Garcia \& Calantone, 2002). We include a four-item scale of innovativeness (two items adapted from Bell, 2005) in our study.

Previous studies in this area did not link variables that are the subject of this paper; however, we had to formulate an adequate and reliable questionnaire, which represented a challenge to research. During the preparation of the final questionnaire, there were several drafts, which were discussed and corrected by two experts from industry and two professors in the field of management. The final version of the questionnaire was structured into four parts: (1) questions about the nature of management functions; (2) questions on the managerial role; (3) questions about intense changes in external and internal environments; (4) questions about firm innovativeness.

Each part of the questionnaire consists of questions in the form of statements that respondents were asked to provide their answers to, expressing their agreement with these statements according to the Likert scale from 1 to 5 . After completing the questionnaire, the reliability of statements that measure certain variables was analyzed through Cronbach's Alpha coefficient. The value of this coefficient for the questionnaire was 0.880 , indicating the very good reliability of the scale, as well as the very good internal coherence of the statements in the questionnaire. 
Strugar Jelača M.: The Role of Management Practice and Business Environment in...

In order to facilitate the accumulation of academic knowledge of management innovation, related to the previously defined research problem and goals, a conceptual framework highlighting the main antecedents and outcomes of management innovations, is shown in Figure 1.

Figure 1. Conceptual framework of the research

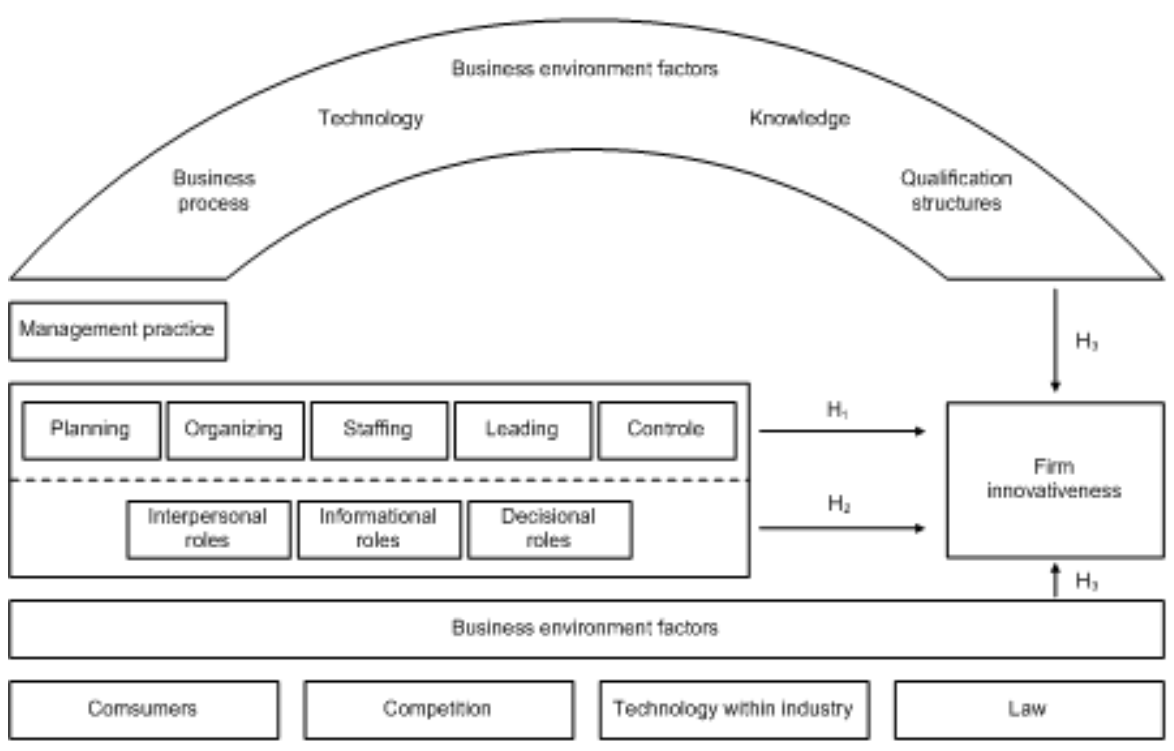

Source: The author

The following hypotheses were set based on the conceptual framework:

- H1: The innovative nature of management functions positively affects innovativeness in large organizational systems.

- H2: The application of managerial roles positively influences the degree of innovativeness in large organizational systems.

- H3: Intensive changes in business environment encourage firm innovativeness.

The hypotheses were tested using the Spearman correlation coefficient and MANOVA through the software package SPSS 20.0. 
Strugar Jelača M.: The Role of Management Practice and Business Environment in...

\section{Results and discussion}

Correlation analysis and MANOVA were applied for the purpose of examining hypothesis $\mathrm{H} 1$, to determine the existence or non-existence of relations and differences in the degree of firm innovativeness, depending on whether the innovative functions are being implemented. Previous studies in this area cover ratio of leading - firm innovativeness (Gumuslouglu \& Ilsev, 2009; Elenkov, Judge, \& Wright, 2005) and staffing - firm innovativeness (Lau \& Ngo, 2004; Stock, Totzauer, \& Zacharias, 2014). In summary, the existing literature indicates that innovative oriented leadership and HR practices are important determinants of innovativeness (Stock et al., 2014, p. 927), but fails to integrate innovation oriented all management functions whit their effect on innovativeness, which the present study did.

Based on the results of the correlation analysis (Table 1), we can conclude that there is a positive correlation of medium intensity between: innovative nature of planning function and the degree of firm innovativeness $(\rho=.344$, Sig = .014); innovative nature of staffing function and the degree of firm innovativeness $(\rho=.373$, Sig $=.008)$; innovative nature of leading function and the degree of firm innovativeness $(\rho=.450$, Sig $=.001)$ and innovative nature of control function and the degree of firm innovativeness $(\rho=.452$, Sig $=.001$ ).

Table 1. Spearman correlation between management functions and firm innovativeness

\begin{tabular}{|c|c|c|}
\hline Functions of management & \multicolumn{2}{|c|}{ Firm innovativeness } \\
\hline \multirow{2}{*}{ Planning } & & $.344^{*}$ \\
\hline & Sig. & .014 \\
\hline \multirow{2}{*}{ Organizing } & & 278 \\
\hline & Sig. & .051 \\
\hline \multirow{2}{*}{ Staffing } & $\rho$ & $.373^{\star \star}$ \\
\hline & Sig. & .008 \\
\hline \multirow{2}{*}{ Leading } & $\rho$ & $.450^{\star \star}$ \\
\hline & Sig. & .001 \\
\hline \multirow{2}{*}{ Control } & & $.452^{\star \star}$ \\
\hline & $\mathrm{Si}$ & .001 \\
\hline
\end{tabular}

Source: The authors' calculation

Thus, the traditional business functions that were based on rigidity are increasingly losing their importance under the influence of constant change. In large organizations, planning that encourages innovation should be based on forecasting future trends in order to set a plan of innovation in their offers of 
Strugar Jelača M.: The Role of Management Practice and Business Environment in...

products and services. Also, the same results were obtained in SMEs, who are aware of the significance of planning function in a dynamic environment, and more capable of performing better in innovation (Mamula \& PopovićPantić, 2015, p. 63). On the other hand, innovation oriented staffing functions should ensure the formation of a human potential at all hierarchical levels, ready to understand the need for change, to accept the idea of a new way of doing business and to implement it effectively. From the viewpoint of leading, previous studies have concentrated on the impacts of transformational leadership on innovativeness, identifying the direct impact (Gumusluoglu \& Ilsev, 2009; Jansen, Vera \& Crossan, 2009). Also, Vaccaro et al. (2012) stated that particularly larger organizations need to make use of transformational leaders to compensate for their complexity and allow management innovation to thrive (p. 28). So, looking at innovative oriented staffing and leading, the same empirical results were obtained by the author, Stock et al. (2014), which emphasize the significant impact of innovative oriented staffing (rewards, training, and development) and leadership to cross-functional R\&D cooperation, which enhance innovativeness. Furthermore, some authors argued that innovative oriented staffing improves employees' innovative behavior and increases the likelihood of product innovation (Rao \& Drazin, 2002; Singh \& Agrawal, 2011). At the end, the growing importance of innovation in the field of business that carries a high degree of risk and uncertainty requires a shift from rigid control functions to a more time-efficient type of control.

For a detailed analysis, a correlation analysis has been made between the statements in the questionnaire determining each management function and firm innovativeness (Table 2).

If a company's management defines its managerial activity based on forecasting from the perspective of planning for customer demand and their preferences towards change, as well as on the movements of market participants then there is a higher level of firm innovativeness $(\rho=.344$, Sig $=$ .018). Also, large organizations which have a strategy focused on innovation enhance overall innovativeness $(\rho=.311$, Sig $=.028)$, which is identical to the results of empirical research conducted by Mamula and Popović-Pantić (2015), who focused their attention on SMEs and reached the conclusion that: "SMEs with clearly defined innovation strategies achieved higher scores on all types of innovation as compared to SMEs that did not report having such a document" (2015, p. 59). Furthermore, encouraging staff toward creative thinking that results in new conceptual solutions in business processes, products and services directly lead to a higher degree of a firm innovativeness $(\rho=.300$, Sig $=.034)$. If the organization's management implements the culture that fosters innovation $(\rho=.412$, Sig $=.003)$, financially supports implementation of new projects $(\rho=.458$, Sig $=.001)$ and implements corrective measures in a timely way $(\rho=.452$, sig. 001$)$, then the degree of 
Strugar Jelača M.: The Role of Management Practice and Business Environment in...

firm innovativeness can be greatly enhanced. As mentioned above, earlier studies, as well as results, have shown that innovative companies with access to financial resources (Mamula \& Popović-Pantić, 2015) can "invest in innovative activities and behave more innovatively" (Mamula \& PopovićPantić, 2015, p. 61; Mosurović \& Kutlača, 2011) which improves overall firm innovativeness.

Table 2. Spearman correlation between the managerial activities and firm innovativeness

\begin{tabular}{|c|c|}
\hline $\begin{array}{l}\text { The managerial activities that describe the types of } \\
\text { management functions }\end{array}$ & $\begin{array}{l}\text { Firm } \\
\text { innovativeness }\end{array}$ \\
\hline $\begin{array}{l}\text { Forecasts of future trends are being used within the planning } \\
\text { process }\end{array}$ & $.344^{\star}$ \\
\hline $\begin{array}{l}\text { Implementation of strategic plans is flexible within the } \\
\text { organization }\end{array}$ & .123 \\
\hline $\begin{array}{l}\text { Several plans are created within the organization, that are } \\
\text { being used depending on current situation }\end{array}$ & .257 \\
\hline $\begin{array}{l}\text { The strategy of organization is focused on innovating the } \\
\text { offer in products and services }\end{array}$ & $.311^{\star \star}$ \\
\hline $\begin{array}{l}\text { There is a clear plan of what should be innovated within } \\
\text { organization }\end{array}$ & .206 \\
\hline $\begin{array}{l}\text { Organizational structure encourages cross-functional } \\
\text { cooperation }\end{array}$ & .164 \\
\hline Organizational structure encourages teamwork & .252 \\
\hline $\begin{array}{l}\text { Employees are encouraged to share knowledge within and } \\
\text { outside the organization }\end{array}$ & .240 \\
\hline $\begin{array}{l}\text { Employees are encouraged to learn and acquire modern } \\
\text { skills }\end{array}$ & .194 \\
\hline Employees are encouraged to discuss ideas & $.300^{*}$ \\
\hline Organization rewards the innovative activity of employees & .275 \\
\hline $\begin{array}{l}\text { Management of organization implements culture that fosters } \\
\text { innovation }\end{array}$ & $.412^{\star \star}$ \\
\hline $\begin{array}{l}\text { Management of organization financially supports the } \\
\text { implementation of new projects }\end{array}$ & $.458^{\star \star}$ \\
\hline $\begin{array}{l}\text { Corrective measures are implemented timely in order to } \\
\text { eliminate deviations while realizing business activities }\end{array}$ & $.452^{\star \star}$ \\
\hline
\end{tabular}

Source: The authors' calculation

Moreover, applying MANOVA has defined the existence of differences in firms' innovativeness depending on the nature of planning function ( $F(8,843)$ $=22.118, p<0.05)$, staffing $(F(25,600)=8.000, p<0.01)$ and leading $(F$ 
Strugar Jelača M.: The Role of Management Practice and Business Environment in...

$(27,200)=34.000, p<0.01)$, as shown in Table 3 . It can be concluded that firms adopting a traditional concept of the management functions cause a lesser degree of firm innovativeness compared to those firms that implement innovative management functions, such as the use of flexible planning, staffing functions concentrated on constant engagement of new qualifications and training of currently employed staff (Lau \& Ngo, 2004; Stock et al., 2014) and transformational leadership styles (Vaccaro et al., 2012).

Table 3. MANOVA between the variables of the nature of management functions and firm innovativeness

\begin{tabular}{|c|c|c|c|c|c|c|}
\hline $\begin{array}{c}\text { The nature of } \\
\text { management } \\
\text { functions }\end{array}$ & $\begin{array}{c}\text { Type III } \\
\text { Sum of } \\
\text { Squares }\end{array}$ & Df & $\begin{array}{c}\text { Mean } \\
\text { Square }\end{array}$ & F & Sig & $\begin{array}{c}\text { Partial } \\
\text { Eta } \\
\text { Squared }\end{array}$ \\
\hline Planning & 22.108 & 8 & 2.764 & 8.843 & $\mathbf{0 . 0 2 6}$ & 0.946 \\
\hline Organizing & .667 & 2 & .333 & 1.067 & 0.425 & 0.348 \\
\hline Staffing & 8.000 & 1 & 8.000 & 25.600 & $\mathbf{0 . 0 0 7}$ & 0.865 \\
\hline Leading & 34.000 & 4 & 8.500 & 27.200 & $\mathbf{0 . 0 0 4}$ & 0.965 \\
\hline Control & 0.500 & 1 & .500 & 1.600 & 0.275 & 0.286 \\
\hline
\end{tabular}

Source: The authors' calculation

Table 4. Spearman rank correlation between managerial role and firm innovativeness

\begin{tabular}{|c|c|c|}
\hline Managerial roles & & Firm innovativeness \\
\hline \multirow{2}{*}{ Figurehead } & $\rho$ & $.674^{\star \star}$ \\
\hline & Sig. & .000 \\
\hline \multirow{2}{*}{ Leader } & $\rho$ & $.560^{\star \star}$ \\
\hline & Sig. & .000 \\
\hline \multirow{2}{*}{ Liaison } & $\rho$ & $.329^{\star}$ \\
\hline & Sig. & .020 \\
\hline \multirow{2}{*}{ Monitor } & $\rho$ & $.383^{\star \star}$ \\
\hline & Sig. & .007 \\
\hline \multirow{2}{*}{ Disseminator } & $\rho$ & $.308^{*}$ \\
\hline & Sig. & .001 \\
\hline \multirow{2}{*}{ Spokesperson } & $\rho$ & .095 \\
\hline & Sig. & .512 \\
\hline \multirow{2}{*}{ Entrepreneur } & $\rho$ & .253 \\
\hline & Sig. & .077 \\
\hline \multirow{2}{*}{ Disturbance handler } & $\rho$ & $.445^{\star \star}$ \\
\hline & Sig. & .001 \\
\hline \multirow{2}{*}{ Resource allocator } & $\rho$ & .167 \\
\hline & Sig. & .246 \\
\hline \multirow{2}{*}{ Negotiator } & $\rho$ & $.435^{\star \star}$ \\
\hline & Sig. & .002 \\
\hline
\end{tabular}

${ }^{*}$ Correlation is significant at the 0.05 level (2-tailed).

** Correlation is significant at the 0.01 level (2-tailed).

Source: The authors' calculation 
Strugar Jelača M.: The Role of Management Practice and Business Environment in...

Hypothesis $\mathrm{H} 2$ was tested through a correlation analysis that established the existence of a statistically significant relation of high intensity between the managerial role of a figurehead $(\rho=0.674 ; p=0.000)$ and leader $(\rho=0.560$; $p=0.000$ ) on the one hand, and firm innovativeness on the other. A statistical correlation of medium intensity can be singled out among managerial roles of liaisons $(\rho=0.329 ; p=0.020)$, monitors $(\rho=0.383 ; p=0.007)$, disseminators ( $\rho=0.308 ; p=0.031)$, disturbance handlers $(\rho=0.445 ; p=0.001)$ and negotiators ( $\rho=0.435 ; p=0.002$ ) compared to the degree of firm innovativeness. However, previous research in the field of managerial roles, was placing emphasis on the analysis of the frequency of use of certain managerial roles depending on the internal and external context (Gibbs, 1994), while other authors analyzed only the internal context of the significance of different roles depending on the hierarchical level and the expertise of managers (Alexander, 1979; Mintzberg, 1973; Paolillo, 1987; Pavett \& Lau, 1983). Until now no study has linked managerial roles and firm innovativeness.

A manager as a figurehead presents the organization as innovative-oriented, and thus encourages finding potential business areas to innovate by enhancing firm innovativeness. The manager as a leader also plays an important role in the creation of an innovative business 'climate', thus building a healthy environment for innovations. Also, such managers should create a network of contacts around themselves and use the established contacts as a potential source of important information that can be used for business purposes. As the present study shows that all three roles that fall into the interpersonal group are significant drivers of firm innovativeness, we should also mention the results of Pavett and Lau (1982), who argue that the significance of applying these roles rises with the hierarchical ladder and duration of employment (Gibbs, 1994). By combining the obtained results it can be concluded that managers at higher levels who occupied that position for a long time frequently applied for interpersonal roles and result in a higher degree of innovation. From the point of an informational group of roles, some managers have the ability to identify new sources of information, which can lead to potential innovation. Such behaviour patterns increase the firm manager's ability to identify, absorb, and utilize new and external knowledge (Cohen \& Levinthal, 1990), leads the organization to be more marketintelligent about the technological changes and consumers' latent needs (Slater \& Narver, 1995), which will raise the levels of innovation in the whole organization. In addition to the manager as a monitor, a manager that acts as a disseminator for a close group of employees fosters firm innovativeness, because they are transmitting current status and trends in the environment, like trends in consumer preference that affect the necessity of change in existing business practices (Sinkula, 1994) in order to enhance customer value. The above mentioned is the indicator of the importance of the 
Strugar Jelača M.: The Role of Management Practice and Business Environment in...

informational roles in the complex business environment (Gibbs, 1994, p. 581 ), which encourages organizations to innovate constantly and leads to an increase in firm innovativeness. Moreover, innovation oriented managers should have the role of disturbance handlers and negotiators when conflicts occur due to different attitudes, tendencies toward risk taking and acceptance of uncertainty that is associated with every innovation.

Table 5 shows the correlation between the variables of the dynamic business environment and firm innovativeness, i.e. the result of testing the hypothesis H3. Based on the results of correlation analysis $(\rho=0.362 ; p=0.011)$ it can be concluded that there is a statistically significant positive correlation of medium intensity between changes in the business environment and firm innovativeness.

Table 5. Spearman correlation between the environment's intense changes and firm innovativeness

\begin{tabular}{|l|l|}
\hline & \multicolumn{1}{|c|}{ Firm innovativeness } \\
\hline Environment's intense changes & Spearman's rho correlation coefficient \\
& $.362^{\star}$ \\
\cline { 2 - 2 } & Sig (2-tailed) \\
& .011 \\
\cline { 2 - 2 } & $\mathrm{N}$ \\
& 50 \\
\hline${ }^{*}$ Correlation is significant at the 0.05 level (2-tailed).
\end{tabular}

Source: The authors' calculation

For a more detailed analysis of the business environment's impact on firm innovativeness, a correlation analysis was conducted between the factors of internal and external environment and firm innovativeness (Table 6).

The empirical results suggest a statistically significant relation of medium intensity between firm innovativeness and the following statements: new qualification structures are continuously being engaged within the firm $(\rho=$ $0.332 ; p=0.019$ ); consumers are inclined toward constantly finding new products or services $(\rho=0.302 ; p=0.033)$; the competitive environment is turbulent $(\rho=0.345 ; p=0.015)$; technological changes within the industry are significant $(\rho=0.352 ; p=0.012)$. Through the professional development and training of existing personnel, elevating them to a higher level of knowledge, as well as through modernization with new qualification-structures, new knowledge is implemented into existing operations thereby increasing the degree of innovativeness. Furthermore, firms that meet the needs of innovative consumers, including the early acquirers and early majority, must constantly innovate to create new or improved products or services in order to retain the existing customer group. In that process, Stock et al. (2014, p. 924) consider customer integration as an important factor in order to identify 
Strugar Jelača M.: The Role of Management Practice and Business Environment in...

frequent changes in consumer preferences and profile adequate new product or service. Also as competition gains intensity and the rate of technological change gains speed, firms need to renew themselves (Vaccaro et al., 2012, p. 28), which has higher firm innovativeness as a result. On the other hand, there is a negative correlation ( $\rho=-0.120 ; p=0.408)$ between the assertion that the legislation of innovative activity often changes and the degree of firm innovativeness. Specifically, across the territory of the Republic of Serbia, the legislation relating to innovative activity has not been fully defined and is constantly subject to change and modification, which itself limits innovation.

Table 6. Spearman correlation analysis of the business environment's factors and firm innovativeness

\begin{tabular}{|l|c|}
\hline \multicolumn{1}{|c|}{ Movement of business environment factors } & $\begin{array}{c}\text { Firm } \\
\text { innovativeness }\end{array}$ \\
\hline Organization encourages fundamental changes in business & .112 \\
\hline $\begin{array}{l}\text { Organization encourages implementation of new } \\
\text { technological principles }\end{array}$ & .076 \\
\hline $\begin{array}{l}\text { Organization prefers finding new knowledge rather than } \\
\text { using the existing one }\end{array}$ & .058 \\
\hline $\begin{array}{l}\text { New qualification structures are continuously being engaged } \\
\text { within the organization }\end{array}$ & $.332^{\star}$ \\
\hline $\begin{array}{l}\text { Consumer's preferences are frequently changing within your } \\
\text { field of work }\end{array}$ & .056 \\
\hline $\begin{array}{l}\text { Your consumers are constantly inclined towards finding new } \\
\text { products or services }\end{array}$ & $.302^{\star}$ \\
\hline $\begin{array}{l}\text { Competitive environment is turbulent within your area of } \\
\text { business }\end{array}$ & $.345^{\star}$ \\
\hline There are significant changes in technology within industry & $.352^{\star}$ \\
\hline $\begin{array}{l}\text { Within your field of work innovative activity is regulated by } \\
\text { laws that change frequently }\end{array}$ & -.120 \\
\hline
\end{tabular}

${ }^{*}$ Correlation is significant at the 0.05 level (2-tailed).

Source: The authors' calculation

\section{Concluding remarks}

So far, little significance has been given to managerial activities that encourage an organization's innovative behavior, although the importance of innovation in achieving competitive advantage is widely known. The sector of large organizations suffers from a small degree of innovation, that is why important driving factor to overcome such situations is management itself, which may be a fertile ground for innovation. An increasingly dynamic business environment completely precludes current ways of doing business and enforces the necessity for firms to react in a timely and proper way by 
Strugar Jelača M.: The Role of Management Practice and Business Environment in...

implementing innovation into existing management practices. In that sense, this study offers several important implications for researchers and practitioners:

- The innovative nature of management functions such as planning, staffing, leading and control, encourage firm innovativeness. Modern business environments that make innovation a prerequisite to sustainable and long-lasting survival require the application of new planning function based on the principle of prognosis, contingent scenario plans and the implementation of flexibility; innovative oriented staffing focused on creating intellectual capital through promoting and mastering new skills for its effective and efficient transfer at all levels of an organization; the leadership function that encourages the behaviour of all employees as catalysts for change; the innovative nature of the control function which must facilitate the transition from a rigid control function and rigid control standards to a more time-efficient type of control. Also, there is a difference between firm innovativeness within large organizational systems that apply innovatively oriented functions of planning, staffing and leading, and those firms that apply traditional managerial functions. The results indicate a decline in the significance of traditional functions of management that are based on rigidity, whereas the modern business environment promotes flexibility and a proactive, reactive style.

- Managerial roles such as a figurehead, leader, liaison, monitor, disseminator, disturbance handler and negotiator lead to a higher degree of firm innovativeness. The set of aforementioned managerial roles represents the profile of a manager who behaves as an agent of change and creates a healthy environment for innovation.

- Some internal factors can be singled out from the list, like employing a new qualification structure as a factor to stimulate firm innovativeness. Looking at the external factors of influence, the most important ones are consumers, competition, and technology. Therefore, firms that serve the consumer category, such as innovators or visionaries, operate in a market characterized by dynamic competitiveness matched with frequent changes in technology and setting new technology standards, so it is necessary to innovate and that is why they have the potential for higher firm innovativeness.

Despite these contributions, this study contains several limitations that represent fertile ground for future research in this area. Limitation of this empirical research is the temporal and spatial framework. The present study analyses the management practices over the period of two years, indicating short-term effects, lacking longitudinal perspective, which might clarify the long-term and dynamic effects of the implemented innovative managerial 
Strugar Jelača M.: The Role of Management Practice and Business Environment in...

behavior. Also, comparative analysis of the existence of innovative management practices in other countries of similar levels of economic and business development should be an open question for future research, as well as comparing management innovations with other variables like indicators of organizational performance in order to determine how and to what extent management innovations can add to an organization's performance.

Therefore, future research into this area should be directed towards setting up a standardized business model for large organizations in transition countries, which promotes innovative ways of doing business and quick response to change and thus increased organizational performance, as well as the probability of success and the achievement of competitive advantage.

\section{References}

Alexander, L.D. (1979). The effect of level in the hierarchy and functional area have on the extent of Mintzberg's roles. Academy of Management Proceedings, 186-189. (00650668).

Amit, R., \& Zott, C. (2001). Value creation in e-business. Strategic Management Journal, 22(6-7), 493-520.

Aranda, D.A., Rata, B.M., \& Duarte, A.R. (2001). Innovation and firm size: An empirical study for Spanish engineering consulting companies. European Journal of Innovation Management, 4(3), 133-142.

Bell, G.G. (2005). Clusters, networks, and firm innovativeness. Strategic Management Journal, 26(3), 287-295. doi:10.1002/smj.448

Birkinshaw, J., \& Mol, M.J. (2006). How management innovation happens. MIT Sloan Management Review, 47(4), 81-88.

Birkinshaw, J., Hamel, G., \& Mol, M.J. (2008). Management innovation. Academy of Management Review, 33(4), 825-845.

Blindenbach-Driessen, F., \& van Den Ende, J. (2010). Innovation management practices compared: The example of project-based firms. Journal of Product Innovation Management, 27(5), 705-724.

Bourgeois, L.J., \& Eisenhardt, K. (1988). Strategic decision processes in high velocity environments: Four cases in the microcomputer industry. Management Science, 34(7), 816-835.

Boyd, B.K., Dess, G.G., \& Rasheed, A.M.A. (1993). Divergence Between Archival and Perceptual Measures of the Environment: Causes and Consequences. Academy of Management Review, 18(2), 204-226.

Casadesus-Masanell, R., \& Zhu, F. (2013). Business model innovation and competitive imitation: The case of sponsor-based business models. Strategic Management Journal, 34(4), 464-482.

Chandler, A.D. (1962). Strategy and structure: Chapters in the history of the industrial enterprise. UK, Cambridge: MIT Press. MA.

Chiesa, V., Frattini, F., Lambertiand, L., \& Noci, G. (2009). Exploring management control in radical innovation projects. European Journal of Innovation Management, 12(4), 416-443. 
Strugar Jelača M.: The Role of Management Practice and Business Environment in...

Cohen, W.M., \& Levinthal, D.A. (1990). Absorptive Capacity: A New Perspective on Learning and Innovation. Administrative Science Quarterly, 35(1), 128-152. doi:10.2307/2393553

Crossan, M.M., \& Apaydin, M. (2010). A Multi-Dimensional Framework of Organizational Innovation: A Systematic Review of the Literature. Journal of Management Studies, 47(6), 1154-1191.

Diaz Fernandez, M., Pasamar Reyes, S., \& Valle Cabrera, R. (2012). Are ambidextrous intellectual capital and HRM needed for an ambidextrous learning. Working paper series, 12(01), Retrieved from http://www.upo.es/serv/bib/wpboam/wpboam1201.pdf

Drew, A.W.S. (2006). Building technology foresight: Using scenarios to embrace innovation. European Journal of Innovation Management, 9(3), 241-257.

Elenkov, D.S., Judge, W., \& Wright, P. (2005). Strategic leadership and executive innovation influence: An international multi-cluster comparative study. Strategic Management Journal, 26(7), 665-682. doi:10.1002/smj.469

Fayol, H. (1949). General and industrial management. UK, London: Pitman.

Feigenbaum, A.V., \& Feigenbaum, D.S. (2005). What Quality Means Today. MIT Sloan Management Review, 46(2), 96.

Garcia, R., \& Calantone, R. (2002). A critical look at technological innovation typology and innovativeness terminology: A literature review. Journal of Product Innovation Management, 19(2), 110-132. doi:10.1016/S0737-6782(01)00132-1

Gibbs, B. (1994). The effects of environment and technology on managerial roles. Journal of Management, 20(3), 581-604.

Green, S.G., Gavin, M.B., \& Aiman-Smith, L. (1995). Assessing a multidimensional measure of radical technological innovation. IEEE Transactions on Engineering Management, 42(3), 203-214. doi:10.1109/17.403738

Guillen, M.F. (1994). Models of management: Work, authority and organization in a comparative perspective. U. S. A, Chicago: University of Chicago Press.

Gumusluoglu, L., \& Ilsev, A. (2009). Transformational leadership and organizational innovation: The roles of internal and external support for innovation. Journal of Product Innovation Management, 26(3), 264-277.

Gupta, K.A., Smith, G.K., \& Shalley, E.C. (2006). The interplay between exploration and exploitation. The Academy of Management Journal, 49(4), 693-706.

Hamel, G. (2006). The why, what, and how of management innovation. Harvard Business Review, 84(2), 72-84.

Hartog, D.N., van Muijen, J.J., \& Koopman, P.L. (1997). Transactional versus transformational leadership: Analysis of the MLQ. Journal of Occupational and Organizational Psychology, 70(1), 19-34.

Ichniowski, C., Shaw, L.K., \& Prennushi, G. (1997). The effects of human resource management practice on productivity: A study of steel finishing lines. American Economic Review, 87(3), 291-313.

Jansen, J.J.P., van den Bosch, F.A.J., \& Volberda, H.W. (2006). Exploratory innovation, exploitative innovation, and performance: Effects of organizational antecedents and environmental moderators. Management Science,52(11), 1661-1674.

Jansen, J.J.P., Vera, D., \& Crossan, M. (2009). Strategic leadership for exploration and exploitation: The moderating role of environmental dynamism. Leadership Quarterly, 20(1), 5-18. 
Strugar Jelača M.: The Role of Management Practice and Business Environment in...

Jaworski, B.J., \& Kohli, A.K. (1993). Market Orientation: Antecedents and Consequences. Journal of Marketing, 57(3), 53-70. doi:10.2307/1251854

Kaplan, R.S. (1998). Innovation action research: Creating new management theory and practice. Journal of Management Accounting Research, 10, 89-118.

Kharović, E., \& Krstić, B. (2015). The Effects of Business Process Management on Improvement of Firm Performance. Industrija, 43(4), 67-87.

Kimberly, J.R., \& Evanisko, M.J. (1981). Organizational innovation: The influence of individual, organizational and contextual factors on hospital adoption of technological and administrative innovations. Academy of Management Journal, 24(4), 689-713.

Lau, C.M., \& Ngo, H.Y. (2004). The HR system, organizational culture, and product innovation. International Business Review, 13(6), 685-703.

Mamula, T., \& Kužet, N. (2015). The role and contribution of coaching style of the 21st century's leader. In: Paper presented at the HR Conference. Belgrade: Retrieved from. Retrieved from http://www.hrconference.org/uploads/1/4/6/3/14634014/radovi_hr_2015_odobrenje za stampu.pdf

Mamula, T., \& Popović-Pantić, S. (2015). Relationship between Innovativeness and Strategic Planning: Empirical research. Industrija, 43(4), 47-65.

Markides, C.C. (2013). Business model innovation: What can the ambidexterity literature teach us?. Academy of Management Perspectives, 27(4), 313-323.

Mazza, C., \& Alvarez, J.L. (2000). Haute couture and Pret-a-Porter: The popular press and the diffusion of management practices. Organization Studies, 21(3), 567588 .

Mcgrath, R.G. (2010). Business models: A discovery driven approach. Long Range Planning, 43(2-3), 247-261.

Mintzberg, H. (1973). The nature of managerial work. New York, USA: Harper \& Row..

Mintzberg, H. (1975). The manager's job: Folklore and fact. Harvard Business Review, 53(4), 50-54.

Mol, J.M., \& Birkinshaw, J. (2009). The sources of management innovation: When firms introduce new management practices. Journal of Business Research, 62(12), 1269-1280.

Mol, M.J., \& Birkinshaw, J. (2012). Relating management innovation to product and process innovation: Private rents versus public gains. In T.S. Pitsis, A. Simpson, \& E. Dehlin (Eds.), Handbook of organizational and managerial innovation. (pp. 13-35). Cheltenham, England: Edward Elgar.

Mol, J.M., \& Birkinshaw, J. (2014). The role of external involvement in the creation of management innovations. Organization Studies, (In Press). Retrieved from http://wrap.warwick.ac.uk/59706/1/WRAP_Mol_the_role_of_external_involvemen t_in_the_creation_of_management_innovations_v_org_studies_final_sage_style. pdf

Morgeson, P.F., Derue, D.S., \& Karam, P.E. (2010). Leadership in teams: A functional approach to understanding leadership. Journal of Management, 36(1), 5-39.

Moriano, A.J., Molero, F., Topa, G., \& Lévy Mangin, J.P. (2014). The influence of transformational leadership and organizational identification on intrapreneurship. International Entrepreneurship Management Journal, 10(1), 103-119. 
Strugar Jelača M.: The Role of Management Practice and Business Environment in...

Mosurović, M., \& Kutlača, (. (2011). Organizational design as a driver for firm innovativeness in Serbia. Innovation: The European Journal of Social Science Research, 24(4), 427-447.

O'connor, G.C., \& Demartino, R. (2006). Organizing for Radical Innovation: An Exploratory Study of the Structural Aspects of RI Management Systems in Large Established Firms. Journal of Product Innovation Management, 23(6), 475-497. doi:10.1111/j.1540-5885.2006.00219.x

Oli, R.M. (2012). Stimulating firm innovativeness: Probing the interrelations between managerial and organizational determinants. Rotterdam, Netherlands: Erasmus University Rotterdam. PhD thesis. Retrieved from http://repub.eur.nl/pub/32343/EPS2012260S\&E9789058923073.pdf

O'sullivan, D., \& Dooley, L. (2009). Applying innovation. UK, London: SAGE Publications Ltd..

Paolillo, J.G.P. (1987). Role Profiles for Managers in Different Functional Areas. Group \& Organization Management, 12(1), 109-118. doi:10.1177/105960118701200108

Pavett, C.M., \& Lau, A.W. (1983). Managerial work: The influence of hierarchical level and functional specialty. Academy of Management Journal, 26(1), 170-177.

Pil, F.K., \& MacDuffie, J.P. (1996). The adoption of high involvement work practices. Industrial Relations, 35(3), 423-455.

Potocan, V., Nedelko, Z., \& Mulej, M. (2012). Influence of organizational factors on management tools usage in Slovenian organizations. Engineering Economics, 23(3), 291-300.

Quiang, L., Maggitti, P.G., Smith, G.P., Tesluk, E.P., \& Katalia, R. (2013). Top management attention to innovation: The role of search selection and intensity in new product introductions. Academy of Management Journal, 56(3), 893-916.

Rao, H., \& Drazin, R. (2002). Overcoming resource constraints on product innovation by recruiting talent from rivals: A study of the mutual fund industry. Academy of Management Journal, 45(3), 491-507.

Sawhney, R. (2013). Implementing labor flexibility: A missing link between acquired labor flexibility and plant performance. Journal of Operations Management, 31(12), 98-108.

Singh, J., \& Agrawal, A. (2011). Recruiting for ideas: How firms exploit the prior inventions of new hires. Management Science, 57(1), 129-150.

Sinkula, J.M. (1994). Market Information Processing and Organizational Learning. Journal of Marketing, 58(1), 34-45.

Slater, S.F., \& Narver, J.C. (1995). Market Orientation and the Learning Organization. Journal of Marketing, 59(3), 63-74. doi:10.2307/1252120

Stefanović, S., Đukić, A., \& Milanović, M. (2015). Clusters in the Function of Innovative Activities and Competitiveness of Enterprises. Industrija, 43(2), 27-51.

Stock, R.M., Totzauer, F., \& Zacharias, A.N. (2014). A Closer Look at Cross-functional R\&D Cooperation for Innovativeness: Innovation-oriented Leadership and Human Resource Practices as Driving Forces. Journal of Product Innovation Management, 31(5), 924-938.

Stock, R.M., \& Zacharias, A.N. (2011). Patterns and performance outcomes of innovation orientation. Journal of the Academy of Marketing Science, 39(6), 870888.

Subramanian, A., \& Nilakanta, S. (1996). Organizational innovativeness: Exploring the relationship between organizational determinants of innovation, types of 
Strugar Jelača M.: The Role of Management Practice and Business Environment in...

innovations, and measures of organizational performance. Omega, 24(6), 631647.

Symeonidis, G. (1996). Innovation, firm size and market structure: Schumpeterian hypotheses and some new themes. doi:10.1787/603802238336

Teece, D.J. (2007). Explicating dynamic capabilities: The nature and microfoundations of (sustainable) enterprise performance. Strategic Management Journal, 28(13), 1319-1350. doi:10.1002/smj.640

Vaccaro, I. (2010). Management innovation: Studies on the role of internal change agent. Rotterdam, Netherlands: Erasmus University Rotterdam. PhD Thesis. Retrieved

from http://www.researchgate.net/publication/254800918_Management_Innovation_St udies_on_the_Role_of_Internal_Change_Agents

Vaccaro, I.G., Jansen, J.P.J., van den Bosch, F.A.J., \& Volberda, H.W. (2012). Management innovation and leadership: The moderating role of organizational size. Journal of Management Studies, 49(1), 28-51.

Vaccaro, I.G., Volberda, H.W., \& van den Bosch, F.A.J. (2012). Management innovation in action: The case of selfmanaging teams. In T.S. Pitsis, A. Simpson, \& E. Dehlin (Eds.), Handbook of organizational and managerial innovation. (pp. 138-162). Cheltenham, England: Edward Elgar.

van den Bosch, F.A.J. (2012). On the necessity and scientific challenges of conducting research into strategic value creating management models. Rotterdam: Erasmus Research Institute of Management.

Volberda, H.W., van den Bosch, F.A.J., \& Heij, C.V. (2013). Management innovation: Management as fertile ground for innovation. European Management Review, 10(1), 1-15.

Zahra, S.A., \& Bogner, W.C. (2000). Technology strategy and software new venture's performance: Exploring effect of the competitive environment. Journal of Business Venturing, 15(2), 135-173.

Zahra, S.A. (1996). Technology strategy and financial performance: Examining the moderating role of the firm's competitive environment. Journal of Business Venturing, 11(3), 189-219. 